\title{
IMPLEMENTASI LARANGAN PARKIR BAGI PENGENDARA KENDARAAN BERMOTOR DI FLYOVER KOTA PEKANBARU BERDASARKAN UNDANG- UNDANG NOMOR 22 TAHUN 2009 TENTANG LALU LINTAS DAN ANGKUTAN JALAN
}

\author{
Jhon Hendri ${ }^{1}$ \\ Program Studi Magister Ilmu Hukum Universitas Lancang Kuning \\ Corresponding Authors Email ${ }^{1}$ : jhonhedri954@gmail.com

\section{Sudi Fahmi ${ }^{2}$} \\ Program Studi Magister Ilmu Hukum Universitas Lancang Kuning \\ Email2 : $\underline{\text { sudi.fahmi@ymail.com }}$ \\ Bahrun Azmi ${ }^{3}$ \\ Program Studi Magister Ilmu Hukum Universitas Lancang Kuning \\ Email3:Bahrunazmi@gmail.com \\ DOI: https://doi.org/10.31764/jmk.v11i2.3161
}

Received: Augt 22, 2020, Accepted: Sept 30, 2020/Published: Okt 31, 2020

\begin{abstract}
This article discusses the implementation of the parking ban for motorists in pekanbaru city flyover. The vehicles that we encountered both four-wheeled and two-wheeled, almost every afternoon until night were found parked at flyover of Sudirman street, Tuanku Tambusai, Sukarno Hatta and HR Subrantas. While the government has clearly given the symbol of the ban to stop the bridge. The traffic law also expressly says that everyone who drives a motor vehicle on the road must comply with the terms of the stop and stop, otherwise it will be sanctioned. This type of research is in the form of legal identification, and testing the effectiveness of applicable laws in society. The result of that research, the implementation of parking ban for motorists in the flyover of Pekanbaru City. Non-compliance with the provisions of the legislation is less effective and maximal, resulting in disruption of road functions. This is because there are still many people who do not know the rules and lack of socialization of Law No. 22 of 2009 from law enforcement officials. Lack of assertiveness of law enforcement officers in applying criminal sanctions, weak public legal awareness. The obstacles faced in the implementation of the parking ban for motorists in pekanbaru city flyover are on the substance of the law, legal structure, legal culture and facilities or facilities and are still limited.
\end{abstract}

Keywords: implementation; parker ban; flyover.

\begin{abstract}
ABSTRAK
Artikel ini membahas tentang implementasi larangan parkir bagi pengendara kendaraan bermotor di flyover kota Pekanbaru. Kendaraan yang kami jumpai baik roda empat maupun roda dua, hampir setiap sore
\end{abstract}


hingga malam hari ditemukan parkir di Flyover jalan Sudirman, Tuanku Tambusai, Sukarno Hatta dan HR Subrantas. Sementara pemerintah sudah dengan jelas memberikan simbol larangan untuk berhenti dijembatan tersebut. Undang-undang lalu lintas pun, tegas mengatakan bahwa setiap orang yang mengemudikan kendaraan bermotor di jalan wajib mematuhi ketentuan berhenti dan parkir, jika tidak, maka akan diberikan sanksi. Jenis penelitian berupa identifikasi hukum, dan menguji efektivitas hukum berlaku dalam masyarakat. Hasil penelitian bahwa, implementasi larangan parkir bagi pengendara kendaraan bermotor di flyover Kota Pekanbaru. Ketidakpatuhan pada ketentuan perundangundang kurang efektif dan maksimal, mengakibatkan terganggunya fungsi jalan. Hal ini disebabkan masih banyaknya masyarakat yang tidak mengetahui peraturan dan kurangnya sosialisasi Undang-Undang Nomor 22 Tahun 2009 dari aparat penegak hukum. Kurang tegasnya aparat penegak hukum dalam menerapkan sanksi Pidana, lemahnya kesadaran hukum masyarakat. Hambatan yang dihadapi pada Implementasi larangan parkir bagi pengendara kendaraan bermotor di flyover kota Pekanbaru adalah pada substansi hukum, struktur hukum, budaya hukum dan sarana atau fasilitas dan masih terbatas.

Kata Kunci : implementasi; larangan parker; flyover.

\section{PENDAHULUAN}

Di Indonesia pengaturan tentang lalu lintas dan angkutan jalan secara nasional diatur di dalam Undang-Undang Republik Indonesia Nomor 22 Tahun 2009 tentang Lalu Lintas dan Angkutan Jalan. Undangundang ini menjadi dasar pedoman dalam penindakan terhadap pelanggaran lalu lintas. Ketentuan pidana denda terhadap setiap pelanggaran lalu lintas secara jelas telah diatur dalam Undang-Undang Nomor 22 Tahun 2009 tersebut. Pelaksanaan penerapan pidana denda di masing-masing daerah berpedoman kepada tabel denda tilang dari hasil koordinasi antara Ketua Pengadilan Negeri, Kepala Kepolisian dan Kepala Kejaksaan Negeri setempat. Penetapan tabel denda ini didasarkan dengan pertimbangan kondisi sosial dan ekonomi masyarakat setempat. Dengan demikian tabel pidana denda dari masing-masing daerah akan bervariasi besar anggaran dananya. 
Dasar hukum berlakunya penetapan tabel denda tilang tersebut adalah berdasarkan SEMA (Surat Edaran Mahkamah Agung) Nomor 4 Tahun 1993. Mahkamah Agung bersama dengan Menteri Kehakiman, Jaksa Agung dan Kepala Kepolisian Republik Indonesia tertanggal 19 Juni 1993 telah mengeluarkan kesepakatan tentang "Tata Cara Penyelesaian Perkara Pelanggaran Lalu Lintas Jalan Tertentu" yang terutama dimaknai sebagai kesepakatan bersama dalam menentukan besarnya pidana denda yang harus dibayar oleh pelanggar lalu lintas dengan memperhatikan kondisi sosial dan ekonomi masyarakat setempat. ${ }^{1}$

Bentuk perlindungan hukum bagi konsumen pengguna jasa parkir maka yang pertama diketahui yaitu hubungan hukum antara konsumen pengguna jasa parkir dengan pihak pengelola parkir untuk mengetahui hak dan kewajiban. Hak dan kewajiban hukum antara satu pihak terhadap pihak lain, dapat muncul karena dari adanya hubungan hukum kedua belah pihak yang disebut perikatan. Berdasarkan Pasal 1233 KUH Perdata yang menegaskan bahwa perikatan lahir karena suatu perjanjian atau karena undang-undang yang dimana Pasal 1313 KUH Perdata menegaskan bahwa suatu persetujuan ialah suatu perbuatan yang satu orang atau lebih mengikatkan diri terhadap satu orang lain atau lebih. Sedangkan perikatan yang timbul karena hukum (undang-undang) timbul karena perbuatan baik itu perbuatan yang sesuai dengan hukum maupun yang melanggar hukum. ${ }^{2}$

Flyover di Kota Pekanbaru sendiri di resmikan pada tanggal 16 Agustus 2012 di resmikan oleh Tim Forum LLAJ (Lalu Lintas Angkutan Jalan) Provinsi Riau yang terdiri dari Ditlantas Polda Riau, Dinas Bina Marga Provinsi Riau, PT. Jasa Raharja cabang Provinsi Riau. Flyover yang

\footnotetext{
1 Haryono, G. 2019. “Pemeriksaan Perkara Pelanggaran Lalu Lintas Berdasarkan Perma No. 12 Tahun 2016 Tentang Tata Cara Penyelesaian Perkara Lalu Lintas". Perspektif.

2 Edi Yanto, dkk, "Perlindungan Hukum Konsumen Jasa Parkir Ditinjau Dari Hukum Positif", Media Keadilan: Jurnal Ilmu Hukum, Volume 11, Nomor 1, April 2020, Hal 115-116.
} 
di bangun dengan anggaran Rp. 700 Milyar berdasarkan anggaran dari Kementrian PU (Pekerjaan Umum) sesuai RPJM (Rencana Pembangunan Jangka Menengah) Kementrian PU (Pekerjaan Umum) Tahun 2010-2014. Flyover sendiri dibangun di 2 titik yaitu Jl. Jend. Sudirman - Jl. Imam Munandar dan Jl. Jend. Sudirman - Jl. Tuanku Tambusai.

Kondisi eksisting Flyover Jl. Sudirman dan Tuanku Tambusai memiliki panjang $460 \mathrm{M}$ dengan lebar $2 \times 6 \mathrm{M}$ dengan sedikit menikung dari arah selatan, kecepatan rata-rata kendaraan $45 \mathrm{~s} / \mathrm{d} 50 \mathrm{~km} / \mathrm{jam}$. Kondisi perlengkapan LLAJ (Lalu Lintas Angkutan Jalan) telah tersedia rambu kecepatan minimal $30 \mathrm{~km} / \mathrm{jam}$ dan rambu larangan melintas bagi sepeda motor. LHR (Lintas Harian Rata-Rata) sepeda motor tercatat 1000 s/d 1500 kendaraan/jam, dengan lebar lengan dipersimpangan cukup besar, $9 \mathrm{M} / 3$ lajur.

Tujuan di bangunnya jembatan Flyover ini ialah untuk mengurangi kemacetan di jalan raya khususnya di jalan Sudirman Kota Pekanbaru, yang menjadi pusat kemacetan di Kota Pekanbaru. Dinas Perhubungan sendiri tidak melarang seutuhnya kendaraan roda dua melintasi Flyover namun lebih membatasi agar tidak terjadi hal yang tidak di inginkan seperti kecelakaan. Maka dari itu dalam membatasi pengguna kendaraan roda dua melintasi Flyover Dishub memasang plank peringatan agar pengendara roda dua hanya boleh melintasi di jam tertentu yaitu pukul 06.00-09.00 WIB dan pukul 16.00-18.00 WIB. Sampai saat ini plank tersebut masih terpasang di kedua titik Flyover tersebut. Dari awal di resmikannya Flyover ini banyak kendaraan roda dua yang mengalami kecelakaan, namun insiden yang paling menyita perhatian ialah kecelakaan tunggal oleh sepeda motor yang menyebabkan korban meninggal dunia pada tahun 2016 lalu. Sehingga dari sinilah awalnya Dinas Perhubungan Provinsi Riau bersama Tim LLAJ (Lalu Lintas Angkutan Jalan) yang terlibat menggelar FGD (Focus Group Discossion) dalam rangka 
Optimalisasi Manajemen Rekayasa Lalu Lintas dalam rangka Mewujudkan Keselamatan, Keamanan, Ketertiban, dan Kelancaran Lalu Lintas Kendaraan Bermotor Roda Dua di Flyover Jalan Sudirman Pekanbaru pada tanggal 10 Oktober 2016 lalu.

Berdasarkan Undang-Undang Nomor 22 Tahun 2009 tentang Lalu Lintas dan Angkutan Jalan Pasal 106 ayat (4) mengatakan setiap orang yang mengemudikan kendaraan bermotor di jalan wajib mematuhi ketentuan: a. rambu perintah atau rambu larangan. Dan dalam Pasal 287 ayat (3) Undang-Undang Nomor 22 Tahun 2009 tentang Lalu Lintas dan Angkutan Jalan yang berbunyi bahwa setiap orang yang mengemudikan kendaraan bermotor di jalan yang melanggar aturan gerakan lalu lintas sebagaimana dimaksud dalam Pasal 106 ayat (4) huruf d atau tata cara berhenti dan parkir sebagaimana dimaksud dalam Pasal 106 ayat (4) huruf e dipidana dengan pidana kurungan paling lama 1 (satu) bulan atau denda paling banyak Rp.250.000,00 (dua ratus lima puluh ribu rupiah). ${ }^{3}$

Seperti kejadian di Pasar Arengka sejumlah kendaraan parkir di dekat Flyover Pasar Arengka, Kota Pekanbaru. Kendaraan tersebut parkir di badan jalan. Posisinya berada di jalur bawah Flyover yang mengarah dari Jalan Soekarno-Hatta menuju Jalan HR Soebrantas. Mobil yang parkir berjejer di ruas jalan tersebut. Keberadaan mobil yang parkir di badan jalan mengganggu arus lalu lintas di sana. Mereka seharusnya parkir di lokasi yang ditentukan. Para pengendara bisa parkir di bagian belakang pasar. Ada juga ruas parkir dekat SPBU Pasar Arengka. Dinas Perhubungan Kota Pekanbaru akan mengambil tindakan terhadap oknum pengendara yang tidak mematuhi aturan, dan bersama Satlantas Polresta Pekanbaru menindak para pengendara yang parkir di badan jalan. Bila

\footnotetext{
${ }^{3}$ Halawa, S. S. 2015. “Penerapan Sanksi Denda Tilang Bagi Pelanggar Lalu Lintas Berdasarkan Undang-Undang Nomor 22 Tahun 2009 Tentang Lalu Lintas Dan Angkutan Jalan Di Wilayah Hukum Kepolisian Resor Kota Pekanbaru". JOM Fakultas Hukum.
} 
tetap melanggar, maka Satlantas melakukan penilangan terhadap mobil yang parkir sembarangan.

Peningkatan pelanggaran lalu lintas menjadi tantangan baru bagi pihak Kepolisian untuk mampu menerapkan sanksi yang mendidik namun tetap memiliki efek jera. Salah satu cara untuk menekan pelanggaran adalah dengan melakukan sanksi administrative (tilang) yang dilakukan oleh pihak kepolisian. Dinas Perhubungan Kota Pekanbaru memasang tanda larangan parkir tidak jauh dari Flyover Pasar Arengka untuk mengantisipasi pengendara yang parkir sembarangan di badan Jalan Soekarno-Hatta, Kota Pekanbaru pada akhir pekan. Dinas Perhubungan Kota Pekanbaru juga berkoordinasi dengan Manajemen dan Rekayasa Lalu lintas Dinas Perhubungan Kota Pekanbaru guna mengantisipasi adanya mobil yang parkir sembarangan di kawasan itu.

Dinas Perhubungan Kota Pekanbaru mengatakan pengendara kerap menggunakan badan jalan sebagai lokasi parkir pada di Sabtu dan Minggu. Tapi pemandangan ini cuma terlihat pada pagi hari saja biasanya saat orang ke pasar kalau siang normal lagi. Tim UPTD (Unit Pelaksana Teknis Dinas) bersama dinas siap menertibkan pengendara yang parkir di badan jalan itu. Keberadaan kendaraan yang parkir sembarangan tidak cuma mengganggu arus lalu lintas. Pengendara juga membahayakan para pengendara lain yang melintas di kawasan itu. ${ }^{4}$

Sistem tilang sering disimpangkan oleh oknum sipil dan oknum anggota polisi untuk saling berkompromi agar kepentingan masingmasing bisa tercapai tanpa mengikuti prosedur yang berlaku. Akibatnya setiap tindakan pelanggaran yang dilakukan masyarakat hanya dicatat dalam surat tilang dan terinfentarisir di Divisi Administrasi Tilang kemudian dilakukan sanksi, dan hanya sampai pada tingkat pencatatan

$4 \quad$ https://pekanbaru.go.id/p/news/dishub-segera-pasang-larangan-parkir-dekat-fly-overpasar-arengka, diakses tanggal 1 April 2020 Pukul 17:00 Wib. 
akhir. Ketika terjadi pengulangan pelanggaran oleh orang yang sama tidak ada peningkatan sanksi yang berarti. Sistem tilang yang dilakukan harus bisa dikelola dengan baik sehingga dalam setiap pelaksanaannya membuahkan efek jera bagi masyarakat pelanggar lalu lintas. Sistem informasi setiap pelanggaran oleh para pengendara di jalan raya harus dapat menjadi dasar penindakan pelanggaran dalam tahapan selanjutnya, artinya informasi pelanggaran yang pernah dilakukan setiap orang harus selalu teridentifikasi oleh setiap anggota polisi yang melakukan tilang.

Pada kenyataannya, kendaraan yang kami jumpai baik roda empat maupun roda dua, hampir setiap sore hingga malam hari ditemukan kendaraan yang parkir di Flyover yang ada dijalan Sudirman, Tuanku Tambusai, Sukarno Hatta dan HR Subrantas. Sementara pemerintah sudah dengan jelas memberikan simbol larangan untuk berhenti dijembatan tersebut. Undang-undang lalu lintas, dengan tegas mengatakan bahwa, setiap orang yang mengemudikan kendaraan bermotor di jalan wajib mematuhi ketentuan berhenti dan parkir akan diberikan sanksi. Hal ini berbahaya karena Flyover tersebut dibangun hanya untuk kendaraan yang melintas. Kendaraan dilarang parkir atau berhenti di sepanjang badan jalan Flyover karena Flyover itu tidak disiapkan bukan untuk kendaraan yang berhenti.

\section{METODOLOGI}

Jenis penelitian adalah penelitian hukum sosiologis. Penelitian hukum sosiologis adalah penelitian yang dilakukan dengan cara mengadakan identifikasi efektivitas hukum berlaku dalam masyarakat. ${ }^{5}$ Metode pendekatan secara empiris dilakukan terhadap bahan hukum non undang-undang ${ }^{6}$, dalam hal ini menguji dan mengkaji data sekunder. Pendekatan penelitian, bersifat deskriptif yaitu penulis mencoba untuk memberikan gambaran dari suatu kenyataan secara

\footnotetext{
5 Soerjono Soekanto, Pengantar Penelitian Hukum, (Jakarta: UI-Press, 1982), Hal. 30.

6 Buku Pedoman Penulisan Tesis Universitas Lancang Kuning Tahun 2019.
} 
lengkap rinci, dan jelas tentang mengenai masalah yang diteliti. Menggunakan pendekatan Undang-Undang (Statue Approach) dan pendekatan kasus (Case Approach).

\section{PEMBAHASAN}

\section{A. Implementasi Larangan Parkir Bagi Pengendara Kendaraan Bermotor Di Flyover Kota Pekanbaru Berdasarkan Undang-Undang Nomor 22 Tahun 2009 Tentang Lalu Lintas Dan Angkutan Jalan}

Masalah lalu lintas yang semakin kompleks seiring dengan pertambahan penduduk dan perkembangan dinamika masyarakat. Hal ini, menuntut Polri untuk bekerja lebih keras dengan paradigma baru agar dapat menjadi polisi yang ideal dimasyarakat. Perubahan dari polisi yang antagonis, yaitu Polisi yang tidak peka terhadap dinamika masyarakat dan menjalankan tugas dengan gaya pemolisian yang bertentangan dengan perubahan masyarakat, menjadi polisi yang protagonis, yaitu polisi yang terbuka terhadap dinamika perubahan masyarakat dan bersedia untuk mengakomodasikan dalam tugas-tugasnya.

Permasalahan lalu lintas di Kota Pekanbaru, lebih lanjut diuraikan sebagai berikut :

\section{Kemacetan}

Kemacetan adalah situasi atau keadaan tersendatnya atau bahkan terhentinya lalu lintas yang disebabkan oleh banyaknya jumlah kendaraan melebihi kapasitas jalan. Kemacetan banyak terjadi di kotakota besar, terutama kota yang tidak mempunyai transportasi publik yang baik atau memadai ataupun juga tidak seimbangnya kebutuhan jalan dengan kepadatan kendaraan. Menurut Arif Budiarto dan Mahmudah bahwa: kemacetan dapat disebabkan antara lain oleh sarana dan prasarana lalu lintas yang masih terbatas, manajemen lalu lintas yang belum berfungsi secara optimal, pelayanan angkutan umum penumpang yang belum memadai, dan disiplin pemakai jalan yang 
masih rendah. Masalah kemacetan lalu lintas merupakan problema yang sangat kompleks dan merupakan fenomena yang tidak mudah untuk diatasi terutama fenomena kemacetan yang terjadi di kota-kota besar, kawasan wisata, kawasan industri, perkantoran, pasar tumpah dan tempat-tempat lain. Berdasarkan hasil penelitian dapat diketahui penyebab terjadinya kemacetan, antara lain :

a) Sikap mental sebagian masyarakat pengguna jalan yang kurang disiplin.

b) Meningkatnya jumlah kendaraan bermotor dari tahun ke tahun yang tidak diimbangi dengan penambahan panjang jalan yang memadai.

c) Ada perbaikan jalan.

d) Menjamurnya pedagang kaki lima, pedagang asongan di badan jalan dan di persimpangan jalan.

e) Pasar tumpah yang secara tidak langsung memakan badan jalan.

f) Pengaturan lampu lalu lintas yang bersifat kaku yang tidak mengikuti tinggi rendahnya arus lalu lintas.

g) Terjadinya kecelakaan, Kemacetan lebih banyak terjadi karena masyarakat yang menonton kejadian kecelakaan atau karena kendaraan yang terlibat kecelakaan belum disingkirkan dari jalur lalu lintas.

h) Tidak tersedianya tempat parkir yang memadai sehingga banyak pengguna jalan yang parkir sembarangan.

i) Terjadinya bencana alam, seperti banjir yang menyebabkan kendaraan tidak dapat melaju secara normal.

j) Kemacetan lalu lintas yang disebabkan karena kepanikan seperti adanya syarat sirene.

2. Pelanggaran

Pelanggaran lalu lintas adalah pelanggaran terhadap persyaratan administrasi dan/atau pelanggaran terhadap persyaratan teknis oleh pemakai kendaraan bermotor sesuai ketentuan Peraturan Perundangundangan lalu lintas yang berlaku. Dengan kata lain, Pelanggaran merupakan suatu tindakan yang tidak sesuai dengan aturan yang ada, baik dalam norma masyarakat atau hukum yang berlaku. Dalam konteks ini pelanggaran lalu lintas adalah suatu tindakan baik sengaja 
ataupun tidak sengaja melakukan perbuatan untuk tidak mematuhi aturan-aturan lalu lintas yang berlaku.

Hasil penelitian menunjukkan bahwa faktor penyebab pelanggaran lalu lintas oleh pengendara di Kota Pekanbaru disebabkan oleh manusia itu sendiri karena kurangnya kesadaran akan peraturan berlalu lintas dan kepentingan-kepentingan manusia yang berlainan menyebabkan manusia ceroboh, lalai, bahkan kesengajaan menjadi faktor dominan terjadinya pelanggaran lalu lintas di Kota Pekanbaru, seperti tidak membawa helm, melawan rambu lalu lintas, menerobos lampu lalu lintas, melewati batas marka jalan, dan melewati batas beban aman kendaraan (motor dinaiki oleh 3 orang). Keadaan di atas membuktikan kualitas kesadaran hukum masyarakat (pemakai jalan) belum memenuhi himbauan disiplin nasional.

3. Kecelakaan

Peristiwa di jalan yang tidak diduga dan tidak disengaja melibatkan kendaraan dengan atau tanpa pengguna jalan lain yang mengakibatkan korban manusia dan/atau kerugian. Berdasarkan hasil penelitian dapat diketahui bahwa penyebab terjadinya kecelakaan lalu lintas di jalan raya antara lain :

a) Volume jalan yang tidak sebanding dengan jumlah kendaraan

b) Petugas pengawas lalu lintas jumlahnya berkurang, serta perlengkapan lalu lintas yang belum lengkap.

c) Para pemakai jalan yang tidak disiplin.

d) Kondisi jalan raya yang kurang baik atau penempatannya yang tidak tepat.

e) Tempat parkir kendaraan dijalan yang tidak teratur.

4. Tingkat Kesadaran Hukum

Kesadaran hukum pada hakekatnya adalah bicara tentang kesadaran atau nilai-nilai yang terdapat di dalam diri manusia tentang 
hukum yang ada atau tentang hukum yang diharapkan. ${ }^{7}$ Masalah kesadaran hukum, menurut Selo Sumarjan berkaitan erat dengan faktor-faktor sebagai berikut :

a) Usaha-usaha menanamkan hukum dalam masyarakat, yaitu menggunakan tenaga manusia, alat-alat, organisasi, dan metode agar masyarakat mengetahui, menghargai, mengakui dan mentaati hukum

b) Reaksi masyarakat yang didasarkan pada sistem nilai-nilai yang berlaku

c) Jangka waktu penanaman hukum diharapkan dapat memberikan hasil.

Terbentuknya kesadaran hukum masyarakat sebagai pengguna jalan pada umumnya dan khususnya kesadaran pengendara dalam berlalu lintas dan menempatkan kendaraannya pada tempatnya sehingga tidak menyebabkab terganngunya fungsi jalan, hal ini juga dipengaruhi oleh faktor-faktor yang dapat dilihat dari beberapa sudut pandang, antara lain mencakup sudut pengetahuan dan pemahamannya terhadap hukum, serta dari sudut sikapnya terhadap hukum. Hal ini dapat dilihat dari pendapat Soerjono Soekanto yang mengemukakan bahwa: untuk mengetahui tingkat kesadaran hukum masyarakat terdapat empat indikator yang dijadikan tolok ukur8, yaitu:

a) Pengetahuan tentang peraturan-peraturan hukum (law awareness).

b) Pengetahuan tentang isi peraturan-peraturan hukum (law acquaintance).

c) Sikap terhadap peraturan-peraturan hukum (legal attitude).

d) Pola-pola perikelakuan hukum (legal behaviour).

\footnotetext{
7 Djatmiko, W. P. 2019. “Rekonstruksi Budaya Hukum Dalam Menanggulangi Carok Di Masyarakat Madura Berdasar Nilai-Nilai Pancasila Sebagai Sarana Politik Kriminal”. Jurnal Hukum Progresif. https://doi.org/10.14710/hp.7.1.40-63.

8 Dwi, M., Matompo, O. S., \& Lestiawati, I. 2019. “Penerapan Sanksi Denda Terhadap Pengendara Motor Yang Tidak Menggunakan Helm (Studi Pada Kepolisian Resort Sigi)". Jurnal Kolaboratif Sains.
} 
Berdasarkan hasil penelitian terhadap tingkat kesadaran hukum masyarakat dapat disimpulkan bahwa tingkat kesadaran hukum masyarakat pengguna jalan khususnya pengguna kendaraan sangatlah rendah. Tingkat kesadaran hukum tidak hanya dapat dilihat dari pengetahuan dan pemahaman masyarakat pengendara terhadap peraturan akan tetapi pengetahuan dan pemahaman tersebut harus tercermin dari perilaku masyarakat pengendara. Berdasarkan hasil penelitian menunjukkan bahwa 25 responden pernah melakukan pelanggaran lalu lintas seperti parker di letter P dan menerobos lampu merah merupakan pelanggaran yang sering dilakukannya. Hasil observasi memperlihatkan bahwa dari sekian banyaknya pengendara khususnya di sepanjang jalan ternyata tidak sedikit yang melanggar peraturan lalu lintas misalnya para pengendara sepeda motor yang masih banyak terlihat parkir yang mengunnakan badan Jalan, Parkir di atas trotoar, mengendarai sepeda motor melawan arus, mengendarai sepeda motor diatas trotoar.

B. Hambatan Implementasi Larangan Parkir bagi Pengendara Kendaraan Bermotor di Flyover Kota Pekanbaru Berdasarkan Undang-Undang Nomor 22 Tahun 2009 Tentang Lalu Lintas Dan Angkutan Jalan

Hambatan yang dihadapi dalam Implementasi larangan parkir bagi pengendara kendaraan bermotor di flyover kota pekanbaru berdasarkan Undang-Undang Nomor 22 Tahun 2009 Tentang Lalu Lintas dan Angkutan Jalan :

a. Substansi Hukum

Hukum merupakan salah satu faktor yang mempengaruhi kesadaran hukum masyarakat. Dalam ilmu hukum terdapat adigium bahwa setiap orang dianggap tahu hukum pada saat hukum dinyatakan berlaku, sehingga secara logika hukum tersebut dapat diterapkan setelah aturan tersebut dinyatakan berlaku. Hukum dibuat 
untuk dilaksanakan, hukum tidak lagi disebut hukum manakala tidak dilaksanakan dalam masyarakat.

Berdasarkan hasil penelitian, 18 responden dari 25 responden tidak tahu terhadap keberadaan aturan penggunaan badan jalan untuk tempat parkir dan aturan mengenai lalu lintas yang menyebabkan terganggunya fungsi jalan, pengendara kendaraan hanya mengikuti petunjuk-petunjuk yang terdapat di jalan berupa rambu-rambu lalu lintas dan arahan dari juru parkir. Para pengendara sepeda motor merasa bahwa peraturan hukum belum bisa memberikan jaminan terhadap keamanan dan keselamatan di jalan raya. Oleh karena itu, dapat dikatakan bahwa pengetahuan masyarakat terhadap aturan sangat rendah.

Mengingat pengetahuan pengendara sepeda motor terhadap aturan sangat rendah, maka pemahamannya pun sangat rendah hal ini berdasarkan hasil penelitian bahwa 23 responden dari 25 responden tidak memahami aturan lalu lintas. Pengendara sepeda motor lebih banyak tidak menggunakan helm SNI, karena mereka tidak memahami ditetapkannya penggunaan helm SNI. Disamping itu juga, banyak pengendara sepeda motor yang telah merubah bentuk kendaraannya (mengurangi atau menambah assesoris kendaraan) seperti menggunakan kaca spion sebelah.

b. Struktur Hukum

Ruang lingkup struktur hukum sangat luar, oleh karena itu di dalam penelitian ini yang dimaksud dengan struktur hukum adalah Kepolisian. Hal ini sesuai dengan Pasal 5 angka (3) huruf (e) Undangundang Nomor 22 Tahun 2009 tentang Lalu Lintas dan Angkutan Jalan bahwa registrasi dan identifikasi kendaraan bermotor dan pengemudi, penegakan hukum, operasional manajemen dan rekayasa lalu lintas, serta pendidikan berlalu lintas, oleh Kepolisian Negara Republik 
Indonesia, penegakan hukum dan pendidikan berlalu lintas merupakan tugas dari Kepolisian, oleh karena itu masalah kesadaran hukum masyarakat pengendara sepeda motor juga dapat dilihat dari sudut struktur hukum dalam hal ini adalah Kepolisian Republik Indonesia.

Berupaya secara terus menerus baik melalui kegiatan preventif meliputi kegiatan penjagaan, pengaturan, patroli dan dikmas lantas berupa penyuluhan tentang pengetahuan lalu lintas maupun kegiatan dalam penegakan hukum berupa penindakan terhadap para pelaku pelanggaran lalu lintas sebagai salah satu upaya. Peranan polisi lalu lintas sangatlah penting karena merupakan sebuah lembaga formal, mempunyai misi untuk mensosialisasikan Undang-undang Lalu Lintas dan Angkutan Jalan kepada para pengendara sepeda motor agar mengetahui peraturan dan tata tertib berlalu lintas di jalan raya. Hal ini sesuai dengan hasil penelitian bahwa warga negara khususnya pengendara sepeda motor yang baik yang sadar dan patuh terhadap hukum yang berlaku maka pihak kepolisian melakukan sosialisasi undang-undang Nomor 22 Tahun 2009 tentang Lalu Lintas dan Angkutan Jalan. Sosialisasi ini berupa penyuluhan atau seminar hukum yang meliputi informasi tentang lalu lintas.

Permasalahan yang diperoleh dari hasil penelitian mengenai struktur hukum atau penegak hukum, antara lain :

1) Petugas yang kurang memadai dilihat dari jumlah personil serta perlengkapan lalu lintas yang belum lengkap.

2) Masih terdapat petugas yang tidak mematuhi peraturan lalu lintas seperti membiarkan terjadinya kemacetan lalu lintas.

3) Kurang tegasnya para penegak hukum dalam menghadapi pelanggaran-pelanggaran pengendara sepeda motor melalui penerapan sanksi. 
Untuk membantu meningkatkan kesadaran hukum masyarakat, penegak hukum harus bertindak tegas, konsisten, penuh dedikasi dan bertanggungjawab dalam menghadapi pengguna jalan.

c. Budaya Hukum

Hukum dapat diartikan sebagai nilai-nilai atau perilaku masyarakat atau kebiasaan masyarakat dalam mematuhi atau mentaati aturan hukum. Seseorang dianggap mempunyai taraf kesadaran hukum yang tinggi apabila perilaku nyatanya sesuai dengan hukum yang berlaku. Hal ini dapat dilihat dari pendapat Lawrence $\mathrm{M}$. Friedman yang menyatakan bahwa kepatuhan hukum yang menunjukkan sampai sejauh manakah perilaku nyata seseorang sesuai dengan hukum yang berlaku. Akan tetapi tidak setiap orang yang mematuhi hokum mempunyai kesadaran hukum yang tinggi. Hal ini disebabkan oleh karena faktor-faktor penyebab terjadinya kepatuhan hukum harus pula dipertimbangkan. Faktor-faktor yang menyebabkan seseorang mematuhi hukum tersebut adalah :

1. Rasa takut pada sanksi hukum yang akan dijatuhkan apabila melanggar.

2. Untuk memelihara hubungan baik dengan penguasa

3. Untuk memelihara hubungan baik dengan rekan-rekan kelompok

4. Oleh karena kepentingan pribadi terjamin oleh hukum

5. Oleh karena hukum sesuai dengan nilai-nilai yang dianut, terutama nilai-nilai keterkaitan dan ketentraman.

Berkaitan dengan budaya hukum, maka ada beberapa permasalahan yang ditemukan, antara lain :

1. Mengetahui

Setelah peraturan perundang-undangan disahkan, maka sejak saat itulah masyarakat dianggap mengetahui adanya suatu aturan, akan tetapi pada kenyataannya masyarakat masih banyak yang belum mengetahuinya. Hal ini dapat dilihat dari hasil penelitian yang menunjukkan bahwa 18 responden dari 25 responden tidak mengetahui adanya aturan lalu lintas yang terdapat dalam Undang-undang Nomor 22 Tahun 2009 tentang Lalu Lintas dan Angkutan Jalan. 
2. Memahami

Masyarakat tidak cukup hanya mengetahui aturan, akan tetapi juga harus memahami isi dari aturan tersebut, seperti tujuan dan manfaat dikeluarkannya peraturan tersebut. Berdasarkan Hasil penelitian menunjukkan bahwa 23 responden dari 25 responden tidak memahami aturan lalu lintas seperti memahami dari penggunaan helm SNI.

3. Mentaati

Setelah mengetahui dan memahami dari isi aturan lalu lintas, maka masyarakat mewujudkan pemahaman tersebut melalui perilaku berupa ketaatan dalam berlalu lintas. Berdasarkan hasil penelitian terhadap ketaatan menunjukkan bahwa :

a. Masyarakat taat pada peraturan lalu lintas karena rasa takut pada sanksi hukum yang akan dijatuhkan apabila melanggar.

b. Masyarakat taat pada peraturan lalu lintas untuk memelihara hubungan baik dengan penguasa, dalam hal ini dengan penegak hukum yaitu Polisi Lalu Lintas.

c. Masyarakat taat pada peraturan lalu lintas untuk memelihara hubungan baik dengan rekan-rekan kelompoknya.

d. Masyarakat taat pada peraturan lalu lintas karena kepentingan pribadi.

e. Masyarakat taat pada peraturan lalu lintas karena hukum tersebut sesuai dengan nilai-nilai yang dianut, terutama nilai-nilai keterkaitan dan ketentraman.

4. Menghargai

Ketika seseorang telah mentaati peraturan, maka sikap menghargai suatu peraturan hukum akan muncul bersamaan dengan hukumnya bahwa hukum tersebut memang wajib untuk ditaati tidak hanya untuk kepentingan dirinya sendiri, juga untuk kepentingan umum. Berdasarkan hasil penelitian, maka budaya hukum masyarakat sangat mempengaruhi terhadap tingkat kesadaran hukum masyarakat. Tidak hanya dapat dilihat dari pengetahuan masyarakat terhadap aturan tetapi juga dapat dilihat dari sikap masyarakat terhadap hukum yang diwujudkan melalui kepatuhan terhadap hukum.

d. Sarana atau Fasilitas

Penegakan hukum dapat berjalan dengan efektif apabila tersedianya sarana atau fasilitas yang memadai, karena sarana atau fasilitas memiliki peranan yang sangat penting dalam penegakan hukum. Berdasarkan hasil penelitian tentang sarana dan prasarana 
yang mempengaruhi peningkatan keselamatan lalu lintas, maka permasalahan yang ada antara lain:

1. Terbatasnya sarana dan prasarana yang mendukung terlaksananya penegakan hukum di bidang lalu lintas antara lain :

a) Perlengkapan jalan seperti : rambu-rambu, marka jalan, penerangan jalan dan tanda-tanda lalu lintas lain dirasakan masih sangat kurang.

b) Mobilitas aparat penegak hukum yang tidak mengimbangi hakekat ancaman.

c) Alat teknologi yang dapat dimanfaatkan untuk tugas penegak hukum, belum bisa dioperasionalkan secara yuridis.

2. Tidak berfungsinya jalan sebagaimana mana mestinya, seperti penggunaan untuk kaki lima, parkir pada badan jalan, dan sebagainya. Rendahnya disiplin pengguna jalan.

C. Upaya Mengatasi Hambatan Implementasi Larangan Parkir Bagi Pengendara Kendaraan Bermotor Di Flyover Kota Pekanbaru Berdasarkan Ketentuan Perundang-Undangan

Idealisme ini bukan semata-mata untuk mencari format hukum yang ideal, melainkan paling tidak mendekati hasil yang optimal untuk membenahi sistem dan mekanisme hukum yang formalistis individual tersebut agar keluar dari kebiasaannya yang hanya berorientasi kepada apa yang disebut model respresif ketimbang responsif. Hukum yang kaku menyulitkan akseptabilitas masyarakat heterogen Indonesia. Hukum yang tidak fleksibel pada gilirannya hanya menimbulkan kompleksitas dan aneka konflik dalam kehidupan sosial, sehingga diperlukan konsepsi hukum yang akseptabel sesuai dengan pola kehidupan bermasyarakat, dan dapat diterima secara sukarela tanpa perlu dipaksakan oleh kekuasaan secara represif.

Upaya yang dilakukan untuk mengatasi hambatan dalam implementasi larangan parkir bagi pengendara kendaraan bermotor di flyover Kota Pekanbaru Berdasarkan Undang-Undang Nomor 22 Tahun 2009 Tentang Lalu Lintas dan Angkutan Jalan, perlu ditegakan, yaitu dengan : 
1. Penegakan hukum bidang pencegahan (preventif) yang meliputi kegiatan pengaturan, penjagaan, pengawalan dan patroli. Dimana dalam pelaksanaannya tidak dapat dipisah-pisahkan, karena merupakan suatu sistem lalu lintas untuk mewujudkan tertib Lalu Lintas.

2. Penegakan hukum bidang penertiban (represif) meliputi penertiban pelanggaran tidak menggunakan helm dan penyidikan kecelakaan lalu lintas dimana penertiban pelanggaran lalu lintas dapat dilakukan secara edukatif yaitu memberikan teguran dan peringatan dengan cara simpatik terhadap para Dinas perhubungan ataupun Satuan Polisi Pampng Praja (Satpol PP). Secara yuridis adalah penertiban dengan menggunakan tilang dan atau menggunakan berita acara singkat/ sumir/ tipiring atau dengan berita acara biasa terhadap pelanggaran yang berpotensi atau memiliki bobot sangat fatal/berat dan dapat merusak fasilitas umum. Proses penegakan hukum lalu lintas ini, baik yang bersifat pencegahan (preventif) maupun penertiban (represif), pelaksanaannya meliputi kegiatan simpatik, penertiban pelanggaran dan penyidikan Lalu Lintas."

Penertiban dilakukan dalam rangka peningkatan ketaatan masyarakat terhadap peraturan, tetapi tindakan tersebut hanya terbatas pada tindakan peringatan dan penghentian sementara kegiatan yang melanggar peraturan. Putusan final atas pelanggaran tersebut merupakan kewenangan Instansi atau pejabat berwenang. Untuk itu, penertiban disini tidak dapat diartikan sebagai tindakan, tetapi penertiban yang dilakukan oleh polisi lalulintas adalah tindakan Non Yustisial. Dalam pelaksanaanya baik upaya bimbingan dan upaya penertiban, maka seorang anggota polisi dalam setiap pelaksanaan tugas harus mendengar laporan permasalahan masyarakat terhadap pelanggaran ketentuan peraturan.

Upaya yang dilakukan untuk mengatasi hambatan dalam Implementasi Larangan Parkir Bagi Pengendara Kendaraan Bermotor Di Flyover Kota Pekanbaru adalah : 
1. Menambah sarana dan prasarana dalam tugas pengawalan terhadap kegiatan Pemerintah Kabupaten/ Kota. Kepatuhan dan kepatutan hukum harus dimulai dari penegak hukum itu sendiri. Bila pelaksanaan penegakan hukum itu telah dijalankan secara tepat, otomatis masyarakat akan mengikuti jejak disiplin para aparatur penegak hukum tersebut karena resiko keteladanan tersebut patut dihargai pihak lain dengan segala resiko yang perlu untuk dipahami dan diterima sebagai sanksi.

2. Meningkatkan jumlah Personil Kepolisian karena di Polres Rokan Hulu dan Polres Pelalawan kekurangan tenaga personil. Mengingat jumlah pejabat yang mau dikawal itu banyak, keterbatasan jumlah personil Kepolisian juga kurang efektif berjalan. Mengingat tugas Kepolisian bukan hanya sebagai pelaksana Tugas Pengawalan Terhadap Kegiatan Pemerintah Kabupaten/Kota, mereka juga sebagai penegak hukum dan bertanggung jawab pada ketertiban masyarakat. Jumlah personil kepolisian yang dimiliki saat ini sangat terbatas.

3. Membangun budaya tertib berlalu lintas Budaya tertib lalu lintas ini hendaknya menjadi kesadaran bagi semua instansi yang ada, sehingga tidak membahayakan diri sendiri dan orang lain. Polisi juga hendaknya cepat dan sigap terhadap kondisi jalan dan untuk segera melakukan koordinasi dengan Dinas Perhubungan dengan diadakan forum lalu lintas.

4. Meningkatkan partisipasi masyarakat melalui sosialisasi kepolisian dalam memberikan penyuluhan Tugas Pengawalan Terhadap Kegiatan Pemerintah Kabupaten/Kota. Masyarakat sendiri harus mempunyai kepekaan terhadap perkembangan hukum, dengan adanya kepekaan hukum oleh masyarakat maka penegakan hukum akan berjalan dengan baik. Peran penting masyarakat juga ikut serta mengawasi aparat penegak hukum yang menjalankan tugas dan wewenang sesuai dengan amanat undang-undang. Masyarakat disini tampak sangat minim.

Tugas untuk membenahi sistem hukum yang sudah sedemikian rupa kebablasan dan tenggelam dalam arus vested interest, adalah suatu keharusan yang tidak terelakkan dan merupakan suatu tugas berat bagi generasi mendatang, khususnya para mahasiswa hukum, intelektual 
hukum, maupun praktisi hukum, serta aparatur hukum. Pembenahan sektor hukum merupakan hal prioritas jika saja kita mau belajar dari kejayaan dan keruntuhan pengalaman pemerintahan masa lalu. Jika hendak menggusur pengalaman pahit masa lalu yang legam itu, atau sekaligus untuk membenahi sistem pemerintahan yang telah mengakar kuat untuk membenahi sistem yang telah mapan itu. Selanjutnya pada tahapan berikutnya adalah melakukan pembenahan sumber daya manusia (SDM) yang profesional dalam bidang hukum dan berorientasi masa depan. Cara yang paling efektif adalah membenahi program kerja dan kinerja, mengakomodasikan tenaga profesional yang mengusai persis bidangnya dan mempunyai integritas dan reputasi serta berdedikasi tinggi dalam rangka pelatihan dan pendidikan melalui program pengembangan yang bersifat meritokrasi dan diterapkan secara komprehensif. Petugas yang bertugas hanya menjalankan fungsi kontrol atau pengawasan saja, perlu melakukan diskusi dengan satuan keamanan dan aparat setempat. Pengawasan adalah menjamin segala sesuatu pelaksanaan pekerjaan yang sesuai dengan apa yang diharapkan, pengawasan sendiri mengikuti perkembangan sekaligus mengantisipasi terjadinya kendala dan mencari solusi.

Hasil Observasi penulis dilapangan bahwa Ketentraman dan ketertiban lalu lintas adalah dengan membina saling membantu dan menolong diantara aparat penertiban dan masyarakat, dinas perhubungan, ${ }^{9}$ dinas pekerjaan umum tanpa mengabaikan kepentingan masing-masing. Tujuannya dalam rangka peningkatan ketaatan dan kepatuhan Upaya Dalam Implementasi Tugas Pengawalan Terhadap Kegiatan Pemerintah Kabupaten/Kota di Provinsi Riau Berdasarkan Undang-Undang Nomor 2 Tahun 2002 Tentang Kepolisian Republik

\footnotetext{
${ }_{9}^{9}$ Hasil Observasi Penulis Dilapangan.
} 
Indonesia. Dengan demikian harapan Pemerintah untuk meningkatkan pelayanan Tugas Pengawalan Terhadap Kegiatan Pemerintah Kabupaten/Kota dalam ketertiban lalulintas dalam keadaan tenteram dan tertib di daerah dapat terwujud. Selain itu pelaksanaan penertiban, ketentraman dan ketertiban lalu lintas juga dapat dilakukan dengan memanfaatkan sarana dan fasilitas umum, meningkatkan kesadaran hukum, Meningkatkan Jumlah Personil Kepolisian serta Tindakan represif.

Pernyataan Dinas Perhubungan tersebut di bantah oleh Pihak Polresta Pekanbaru, Menurut Pihak Dinas Perhubungan Kota Pekanbaru sengaja Melegalkan Parkir dengan memberikan izin parkir di badan jalan yang mana Parkir tersebut menggangu dan menyebabkan kemacetan yang luar biasa. Selain itu Belum adanya sanksi tegas berupa sanksi pidana kepada pelaku juru parkir ataupun pelaku pengguna kendaraan yang Parkir sembarangan mengakibatkan terganggunya fungsi jalan tersebut sehingga masalah seperti ini terus terjadi di Kota Pekanbaru.

Ketentuan pasal 287 ayat (1) Undang-Undang Nomor 22 tahun 2009 memberikan ancaman pidana kurungan paling lama 2 (dua) bulan atau denda paling banyak Rp.500.000,- (lima ratus ribu rupiah) bagi pengendara kendaraan bermotor yang melanggar aturan perintah atau larangan rambu lalu lintas. Ketentuan lain di pasal 287 ayat (3) memberikan ancaman pidana kurungan paling lama 1 (satu) bulan atau dengan paling banyak Rp.250.000,- (dua ratus ribu rupiah) bagi pengendara kendaraan bermotor yang melanggar tata cara berhenti dan parkir.

Sanksi pidana pasal 287 Undang-Undang Nomor 22 tahun 2009 tersebut di atas bukanlah kata putus, terutama jika parkir sembarangan benar-benar menyebabkan terjadinya kecelakaan lalu lintas, apalagi sampai menimbulkan luka berat dan korban meninggal dunia. Pelaku 
parkir sembarangan adalah Pengemudi, pemilik Kendaraan Bermotor yang melanggar ketentuan pasal 106 ayat (4) huruf a dan huruf e tentang ketentuan rambu lalu lintas dan parkir, sehingga menimbulkan yaitu pihak-pihak yang terlibat kecelakaan akibat parkir sembarangan tersebut. Selanjutnya pelaku parkir sembarangan bisa dituntut oleh pihak-pihak tersebut. Misalnya jika dalam kecelakaan tersebut atas seluruh biaya pengobatan dan/atau pemakaman korban (pasal 235 ayat (1) dan (2)). Dia juga harus membayar ganti kerugian atas tuntutan ahli waris korban meninggal sesuai putusan pengadilan, karena alasan bahwa keluarga korban sesuai ketentuan Pasal 1370 KUH Perdata. Disamping itu, kerugian akibat kerusakan kendaraan dan barang-barang juga harus ditanggung pula oleh si pemarkir nakal.

Fakta menunjukkan bahwa begitu ada satu saja kendaraan bermotor diparkir di lokasi seperti itu, maka arus lalu lintas langsung tersendat. Di beberapa ruas jalan Seperti Jalan Tanjunpura dan Gajahmada dengan dua lajur searah jamak terjadi pemandangan dimana pada lajur sebelah kanan terjadi antrean kendaraan yang akan berbelok ke kanan menunggu lampu lalu lintas yang masih merah, sementara di satu lajur sisanya yaitu lajur kiri diparkir sebuah kendaraan roda empat di badan jalan. Praktis seluruh badan jalan tertutup oleh kendaraan yang sedang berhenti. Satu lajur menunggu giliran lampu menjadi hijau. Jika di antara dua baris kendaraan berhenti tersebut tersisa ruang melintas yang seringkali tak cukup lebar untuk dilewati kendaraan roda empat. Paling-paling kendaraan roda dua kendaraan yang akan berbelok ke kiri di persimpangan jalan akan bisa melintas dengan mudah. Namun gara-gara satu kendaraan saja yang parkir sembarangan, pengguna lajur kiri tak mendapatkan haknya.

Situasi semakin berbahaya jika arus kendaraan dari arah belakang mengalir cukup deras misalnya sebagai imbas dari jalur yang searah dan 
penghujung turunan fly over yang lazimnya memang kendaraan melaju dengan kencang. Jika mendadak pengendara harus mengurangi kecepatannya dengan tiba-tiba akibat arus kendaraan terganggu oleh satu hal itu sangat membahayakan bagi jiwa, baik diri maupun orang lain. Padahal umumnya sebagian besar pengguna jalan umum adalah pengendara sepeda motor yang jika dihadapkan pada situasi lalu lintas ekstrim semacam itu akan rawan terjadi peristiwa fatal di luar kendali pengendara.

Satu kendaraan saja sudah berimbas dan berdampak panjang, apalagi prakteknya, pelanggaran yang sama dilakukan oleh beberapa (pengguna) kendaraan. Jika saja mereka berfikir bahwa akibat dari pelanggaran yang dilakukannya berbuntut risiko kecelakaan, bahkan hilangnya nyawa pengguna jalan, boleh jadi mereka tidak akan melakukan atau mengulanginya. Atau jika saja mereka merasa malu berperilaku tidak elok parkir sembarangan, mungkin mereka akan berfikir ulang melakukan pelanggaran itu. Lebih baik mencari tempat untuk parkir kendaraan yang lebih aman dan nyaman. Pun andai saja mereka mempertimbangkan ancaman hukuman dari tindakan melanggar hukum berlalu lintas seperti itu, seharusnya mereka menghidarkan diri dari parkir di tempat larangan parkir. Maka alangkah bagusnya jika semua pengguna jalan membiasakan diri untuk tidak parkir sembarangan apalagi di tempat larangan parkir. Pasti akan merasakan ketenangan, kenyamanan, dan kepuasan jika parkir dilakukan pada tempat yang benar, karena telah berupaya patuh hukum, mencegah dari kerugian diri dan orang lain, serta bijak menyikapi hak dan kewajiban berlalu lintas.

Namun jika dalam kondisi tertentu terpaksa harus parkir kendaraan di tempat yang tidak disediakan khusus untuk itu, setidak-tidaknya tidak parkir di tempat terlarang. Itupun dengan harapan pengguna jalan lain bertindak hati-hati pada kendaraan kita. Mudah-mudahan pula dia tahu 
dan ingat bahwa diantara pengertian kelalaian adalah berkendara dengan wajar dan penuh konsentrasi (Pasal 106 ayat (1) Undang-Undang Nomor 22 Tahun 2009 Tentang Lalu Lintas Dan Angkutan Jalan), sehingga dia tidak gegabah menyalahkan pengguna jalan lain yang karena terpaksa harus memarkir kendaraannya di tempat yang tidak benar-benar disediakan untuk keperluan itu.

\section{KESIMPULAN}

Implementasi larangan parkir bagi pengendara kendaraan bermotor di flyover Kota Pekanbaru kurang efektif dan maksimal. Hal ini dikarenakan masih banyaknya masyarakat yang tidak mengetahui peraturan tersebut, kurangnya sosialisasi Undang-Undang Nomor 22 Tahun 2009 dari aparat penegak hukum. Kurang tegasnya aparat penegak hukum dalam menerapkan sanksi pidana, kesadaran hukum masyarakat yang masih minim. Upaya yang dilakukan untuk mengatasi hambatan muncul adalah dengan membina, membantu dan menolong diantara aparat penertiban bersama masyarakat, dinas perhubungan, dinas pekerja umum tanpa mengabaikan kepentingan masing-masing. Memanfaatkan sarana dan fasilitas umum, kesadaran hukum, menambah jumlah Personil Kepolisian di lingkup lalu lintas serta tindakan represif bagi pelanggar.

\section{DAFTAR PUSTAKA}

\section{Buku}

Soerjono Soekanto, 1982, Pengantar Penelitian Hukum, (Jakarta: UI-Press) Buku Pedoman Penulisan Tesis Universitas Lancang Kuning Tahun 2019. Kamus Besar Bahasa Indonesia, 2005, Departemen Pendidikan dan Kebudayaan, Jakarta: Balai Pustaka.

Kementerian Pekerjaan Umum Inspektorat Jenderal, 2012 Peraturan Perundang-Undangan Tentang Jalan.

Majelis Permusyawaratan Rakyat Republik Indonesia, 2010, Panduan Pemasyarakatan Undang-Undang Dasar Republik Indonesia Tahun 1945 (Sesuai dengnan Urutan Bab, Pasal dan ayat), Jakarta: Sekertaris Jendral MPR RI. 
Jhon Hendri, Sudi Fahmi, \& Bahrun Azmi | Implementasi Larangan Parkir bagi Pengendara Kendaraan Bermotor di Flyover...

Markas Besar Kepolisian Negara Republik Indonesia Akademi Kepolisian.

Jurnal

Edi Yanto, dkk, 2020, "Perlindungan Hukum Konsumen Jasa Parkir Ditinjau Dari Hukum Positif", Media Keadilan: Jurnal Ilmu Hukum, Volume 11, Nomor 1, April.

Djatmiko, W. P. 2019. "Rekonstruksi Budaya Hukum Dalam Menanggulangi Carok Di Masyarakat Madura Berdasar NilaiNilai Pancasila Sebagai Sarana Politik Kriminal". Jurnal Hukum Progresif. https://doi.org/10.14710/hp.7.1.40-63Haryono, G. 2019. "Pemeriksaan Perkara Pelanggaran Lalu Lintas Berdasarkan Perma No. 12 Tahun 2016 Tentang Tata Cara Penyelesaian Perkara Lalu Lintas". Perspektif.

Dwi, M., Matompo, O. S., \& Lestiawati, I. 2019. “Penerapan Sanksi Denda Terhadap Pengendara Motor Yang Tidak Menggunakan Helm (Studi Pada Kepolisian Resort Sigi)". Jurnal Kolaboratif Sains.

Halawa, S. S. 2015. Penerapan Sanksi Denda Tilang Bagi Pelanggar Lalu Lintas Berdasarkan Undang-Undang Nomor 22 Tahun 2009 Tentang Lalu Lintas Dan Angkutan Jalan Di Wilayah Hukum Kepolisian Resor Kota Pekanbaru. JOM Fakultas Hukum. https://pekanbaru.go.id/p/news/dishub-segera-pasanglarangan-parkir-dekat-fly-over-pasar-arengka, diakses tanggal 1 April 2020 Pukul 17:00 Wib.

\section{Peraturan Perundang-undangan}

Undang-Undang Dasar NRI 1945

Undang-Undang Negara Republik Indonesia Nomor 2 Tahun 2002 tentang Kepolisian Negara Republik Indonesia

Undang-Undang Negara Republik Indonesia Nomor 22 Tahun 2009 tentang Lalu Lintas dan Angkutan Jalan

Peraturan Kapolri Nomor 10 Tahun 2012 tentang Pengaturan Lalu Lintas Dalam Keadaan Tertentu dan Penggunaan Jalan Selain Untuk Kegiatan Lalu Lintas.

Peraturan Pemerintah Nomor 58 Tahun 2010 tentang Pelaksanaan Kitab Undang-Undang Hukum Acara Pidana.

Peraturan Pemerintah Nomor 34 Tahun 2006 tentang Jalan

Kitab Undang-Undang Hukum Pidana. 